\title{
Association of angiotensin-converting enzyme inhibitor therapy and comorbidity in diabetes: results from the Vermont diabetes information system
}

\author{
Maria E Ramos-Nino*1, Charles D MacLean² and Benjamin Littenberg ${ }^{2,3}$
}

\author{
Address: ${ }^{1}$ University of Vermont, Department of Pathology, Burlington, Vermont, USA, ${ }^{2}$ University of Vermont, General Internal Medicine, \\ Burlington, Vermont, USA and ${ }^{3}$ University of Vermont, Department of Nursing, Burlington, Vermont, USA \\ Email: Maria E Ramos-Nino* - Maria.Ramos@uvm.edu; Charles D MacLean - charles.maclean@vtmednet.org; \\ Benjamin Littenberg - benjamin.littenberg@vtmednet.org \\ * Corresponding author
}

Published: 5 December 2008

BMC Endocrine Disorders 2008, 8:17 doi:10.1186/1472-6823-8-17

This article is available from: http://www.biomedcentral.com/1472-6823/8/17

(c) 2008 Ramos-Nino et al; licensee BioMed Central Ltd.

This is an Open Access article distributed under the terms of the Creative Commons Attribution License (http://creativecommons.org/licenses/by/2.0), which permits unrestricted use, distribution, and reproduction in any medium, provided the original work is properly cited.
Received: II September 2008

Accepted: 5 December 2008

\begin{abstract}
Background: Angiotensin converting enzyme inhibitors (ACE inhibitors) reduce peripheral vascular resistance via blockage of angiotensin converting enzyme (ACE). ACE inhibitors are commonly used to treat congestive heart failure and high blood pressure, but other effects have been reported. In this study, we explored the association between ACE inhibitor therapy and the prevalence of comorbid conditions in adults with diabetes

Methods: We surveyed 1003 adults with diabetes randomly selected from community practices. Patients were interviewed at home and self-reported their personal and clinical characteristics including comorbidity. Current medications were obtained by direct observation of medication containers. We built logistic regression models with the history of comorbidities as the outcome variable and the current use of ACE inhibitors as the primary predictor variable. We adjusted for possible confounding by social (age, sex, alcohol drinking, cigarette smoking) and clinical factors (systolic blood pressure, body mass index (BMI), glycosolated hemoglobin (AIC), number of comorbid conditions, and number of prescription medications).
\end{abstract}

Results: ACE users reported a history of any cancer (except the non-life-threatening skin cancers) less frequently than non-users ( $10 \%$ vs. I5\%; odd ratio $=0.59 ; 95 \%$ confidence interval $[0.39,0.89]$; $P=0.0 \mathrm{I})$; and a history of stomach ulcers or peptic ulcer disease less frequently than non-users $(\mathrm{I} 2 \%$ vs. $16 \%$, odd ratio $=0.70,[0.49, \mathrm{I} .0 \mathrm{I}], P=0.06)$. After correcting for potential confounders, ACE inhibitors remained significantly inversely associated with a personal history of cancer (odds ratio $=0.59,[0.39,0.89] ; P=0.01)$ and peptic ulcer disease (odd ratio $=0.68,[0.46,1.00], P=0.05)$.

Conclusion: ACE inhibitor use is associated with a lower likelihood of a history of cancer and peptic ulcers in patients with diabetes. These findings are limited by the cross sectional study design, self-report of comorbid diagnoses, and lack of information on the timing and duration of ACE inhibitor use. Further research is needed to confirm these associations and understand their mechanisms. 


\section{Background}

Although introduced for the treatment of hypertension, angiotensin converting enzyme (ACE) inhibitors are also able to reduce morbidity and mortality in congestive heart failure and post myocardial infarction, and to prevent reinfarction (reviewed in [1]), but have been found to have other benefits. For example, ACE inhibitors have been observed to slow the progression of diabetic nephropathy $[2,3]$. Lever $e t$ al. [4] found that users of ACE inhibitors exhibited a reduced risk of cancer $(\mathrm{RR}=0.63 ; 95 \% \mathrm{CI}$, 0.41-0.93). Koh et al. [5] found that individuals possessing low-activity ACE alleles were at a reduced risk of breast cancer, suggesting that inhibition of the angiotensin II effect by blockade of ACE could be potential targets for the prevention and treatment of breast cancer.

Diabetes increases the risk of vascular complications [6]. Evidence from large-scale clinical trials has suggested that attenuation of the renin-angiotensin-aldosterone system by ACE inhibitors may reduce cardiovascular morbidity and mortality in diabetic patients with established cardiovascular disease [7-9]. ACE inhibitors may also increase survival in diabetes patients without heart disease and some large studies have shown that ACE inhibitors were able to reduce the risk of developing diabetes itself [10]. Here, we report the association between ACE inhibitor therapies and cancer or stomach/peptic ulcer disease in diabetic patients.

\section{Methods}

This study is part of a larger project, the Vermont Diabetes Information System (VDIS), a study of 8,855 adults with diabetes in primary care practices [11]. The subjects comprised all diabetic adults in 69 practices in Vermont and adjacent New Hampshire and New York. A field survey was completed at study baseline in a sub-sample of subjects. Patients' names were randomly sorted and patients contacted by telephone until approximately $15 \%$ of patients from each practice agreed to participate in the field survey. Four patients were dropped from the analysis due to incomplete information leaving a final sample of 1,003 .

Subjects completed a questionnaire at home and were visited by a trained research assistant who reviewed the questionnaire responses, assisted the subject with any missing or unacceptable responses, reviewed the subject's medications, and measured their blood pressure, height and weight using a portable sphygmomanometer, stadiometer, and scale. Race, education, income, marital status, functional status, smoking, alcohol consumption, and comorbid conditions were obtained by questionnaire. Prior to the interview, patients were instructed to gather all current medications, including over the counter preparations, for review by the research assistant. The medica- tion list was ascertained by direct observation of the medication container with recording of the drug name, dose, frequency, and route of administration. Duration of therapy was not recorded.

To determine comorbidity, we used a modification of the Self-Administered Comorbidity Questionnaire [12] in which we asked each patient to indicate whether they have had the following conditions: coronary artery disease (CAD), congestive heart failure (CHF), peripheral vascular disease (PVD), cerebrovascular accident or stroke (CVA), Alzheimer or any other dementia, asthma/chronic obstructive lung disease, rheumatic disease (rheumatoid arthritis, lupus or polymyalgia rheumatica), stomach ulcers or peptic ulcer disease (PUD), cirrhosis, paralysis, renal insufficiency, microvascular complications (eye, nerve, kidney damage related to diabetes), AIDS/HIV, and depression. All patients had diabetes which was not included in the comorbidity count. Patients were classified as having cancer if they reported any non-skin cancer including leukemia or lymphoma. Specific cancer sites and dates of diagnosis were not recorded.

The interviews occurred between July 2003 and March 2005. Most laboratory data were obtained from the

Table I: Baseline characteristics of I,004 adults with diabetes.

\begin{tabular}{lc}
\hline Characteristic & $n$ (\%) or mean (sd) \\
\hline Ace Inhibitors use & $445(44.3 \%)$ \\
Men & $457(45.5 \%)$ \\
Age, years & $64.8(12.0)$ \\
Systolic Blood Pressure, mmHg & $140.3(19.6)$ \\
Glycosolated hemoglobin AIC, \% & $7.12(1.3)$ \\
Body mass index, kg/m ${ }^{2}$ & $33.81(7.4)$ \\
Alcohol use & $274(27.4 \%)$ \\
Cigarette smoking & $170(17.0 \%)$ \\
Number of comorbid conditions & $1.8(1.7)$ \\
Number of prescription medications & $6.7(3.8)$ \\
Rheumatic disease & $142(14.2 \%)$ \\
Asthma/chronic obstructive lung disease & $203(20.2 \%)$ \\
Coronary artery disease & $193(19.2 \%)$ \\
Cancer & $126(12.6 \%)$ \\
Congestive heart failure & $172(17.2 \%)$ \\
Cirrhosis & $18(1.8 \%)$ \\
Stroke & $118(11.8 \%)$ \\
Depression & $351(35.0 \%)$ \\
Foot ulcers & $111(11.2 \%)$ \\
Foot/leg pain & $291(31.0 \%)$ \\
Microvascular disease & $170(17.0 \%)$ \\
Paresis & $30(3.0 \%)$ \\
Peptic ulcer disease & $143(14.3 \%)$ \\
Peripheral vascular disease & $88(8.8 \%)$ \\
Renal problems & $50(5.0 \%)$ \\
Sexual dysfunction & $244(26.6 \%)$ \\
Stomach emptying & $56(6.2 \%)$ \\
&
\end{tabular}

$s d=$ standard deviation; $n=$ number of subjects with the characteristic 
Table 2: Univariate associations between comorbidity and ACE inhibitor therapy.

\begin{tabular}{lccc}
\hline Comorbidity & $\begin{array}{c}\text { ACE inhibitor non- users } \\
n(\%)\end{array}$ & $\begin{array}{c}\text { ACE inhibitor users } \\
n(\%)\end{array}$ & Odds Ratio \\
\hline Rheumatic disease & $80(14.3)$ & $62(13.9)$ & 0.86 \\
Asthma/COPD & $116(20.8)$ & $87(19.6)$ & 0.97 \\
CAD & $98(17.6)$ & $95(21.4)$ & 0.93 \\
Cancer & $\mathbf{8 2 ( 1 4 . 7 )}$ & $\mathbf{4 4}(9.9)$ & 1.27 \\
CHF & $87(15.6)$ & $85(19.1)$ & 0.64 \\
Cirrhosis & $9(1.6)$ & $9(2.0)$ & $\mathbf{0 . 0 2}$ \\
CVA & $70(12.5)$ & $48(10.8)$ & 0.14 \\
Depression & $198(35.5)$ & $153(34.4)$ & 1.28 \\
Paresis & $17(3.1)$ & $13(2.9)$ & 0.63 \\
PUD & $\mathbf{9 0 ( 1 6 . 1 )}$ & $\mathbf{5 3}(11.9)$ & 0.93 \\
PVD & $45(8.1)$ & $43(9.7)$ & 0.95 \\
\end{tabular}

$N=1003$

patients' local clinical laboratories, which all use the same Diabetes Control and Complications Trial/Epidemiology of Diabetes Interventions and Complications high performance, liquid chromatography (HPLC) method for the determination of glycosylated hemoglobin (A1C). Less than $1 \%$ of $\mathrm{A} 1 \mathrm{C}$ tests were done using the Bayer DCA 2000 immunoassay point of care instrument, which has been shown to compare favorably with the HPLC method [13].

The research protocol was carried out in compliance with the Helsinki Declaration and was approved by the Committee on Human Research of the University of Vermont. The interviewed subjects provided written informed consent. The full study protocol and variables, and the medication profiles of the subjects have been previously reported $[11,14]$.

We performed a cross sectional analysis of the interviewed subjects at the time of their enrollment in the VDIS trial. We explored the association between rheumatic disease, asthma/COPD, CAD, cancer, CHF, cirrhosis, CVA, depres- sion, paresis, PUD, PVD, and the use of ACE inhibitors therapy using logistic regression with each condition as the outcome variable and the use of ACE inhibitors as the primary predictor variable. We then adjusted for possible confounding by social and clinical factors including gender, age (years), systolic blood pressure ( $\mathrm{mmHg})$, glycosylated hemoglobin level (A1C in mg\%), body mass index (BMI in $\mathrm{kg} / \mathrm{m}^{2}$ ), current alcohol use (yes/no), current cigarette use (yes/no), number of comorbidities, and number of prescription medications. The selection of these potential confounding conditions was based on clinical and epidemiologic judgment and not on statistical determinants. We used Stata/SE 9.2 (StataCorp, College Station, TX) for all analyses.

\section{Results}

The study population was representative of adults with diabetes in primary care practices in Northern New England. See Table 1.

Table 2 presents the univariate associations between each comorbid condition and the use of ACE inhibitors. Can-

Table 3: Univariate associations between ACE inhibitor therapy and other patient characteristics.

\begin{tabular}{|c|c|c|c|c|}
\hline Characteristic & $\begin{array}{c}A C E \text { inhibitor users } \\
\% \text { or mean }(s d)\end{array}$ & $\begin{array}{c}\text { ACE inhibitor users } \\
\% \text { or mean (sd) }\end{array}$ & Odds Ratio & $P$ \\
\hline Number of subjects & 558 & 445 & & \\
\hline Age, years & $65.2(12.1)$ & 64.3 (11.9) & 0.99 & 0.24 \\
\hline Men & $41.5 \%$ & $50.6 \%$ & 1.44 & 0.004 \\
\hline Systolic Blood Pressure & | 39.7 (18.8) & $|4| .0$ (20.5) & 1.00 & 0.28 \\
\hline Glycosolated & $7.1(1.3)$ & $7.2(1.3)$ & 1.10 & 0.05 \\
\hline \multicolumn{5}{|l|}{ hemoglobin AIC, \% } \\
\hline Body mass index, $\mathrm{kg} / \mathrm{m} 2$ & $33.2(7.3)$ & $34.6(7.4)$ & 1.03 & 0.002 \\
\hline Alcohol drinking & $30.2 \%$ & $23.8 \%$ & 0.72 & 0.03 \\
\hline Cigarette smoking & $18.5 \%$ & $15.1 \%$ & 0.78 & 0.15 \\
\hline Comorbidity conditions & $\mathrm{I} .8 \mathrm{I}(0 . \mathrm{l})$ & $\mathrm{I} .83(0.1)$ & 1.01 & 0.82 \\
\hline Number of prescription meds & $6.2(3.9)$ & $7.2(3.5)$ & 1.10 & $<0.0001$ \\
\hline
\end{tabular}


Table 4: Univariate associations between cancer and other patient characteristics.

\begin{tabular}{|c|c|c|c|c|}
\hline Characteristic & $\begin{array}{l}\text { Cancer Patients } \\
\% \text { or mean (sd) }\end{array}$ & $\begin{array}{c}\text { Non-Cancer Patients } \\
\% \text { or mean (sd) }\end{array}$ & Odds Ratio & $P$ \\
\hline Number of subjects & 126 & 877 & & \\
\hline ACE inhibitor therapy & $34.9 \%$ & $45.7 \%$ & 0.64 & 0.02 \\
\hline Age, years & $69.1(10.2)$ & $64.2(12.1)$ & 1.04 & $<0.001$ \\
\hline Male & $42.1 \%$ & $46.1 \%$ & 0.85 & 0.40 \\
\hline Systolic Blood Pressure, $\mathrm{mmHg}$ & $143.0(20.9)$ & $139.9(19.4)$ & I.0I & 0.10 \\
\hline Body mass index, $\mathrm{kg} / \mathrm{m}^{2}$ & $32.6(6.8)$ & $34.0(7.5)$ & 0.97 & 0.06 \\
\hline Alcohol drinking & $25.4 \%$ & $27.6 \%$ & 0.89 & 0.60 \\
\hline Cigarette smoking & $11.1 \%$ & $17.8 \%$ & 0.58 & 0.06 \\
\hline Number of comorbid conditions & $1.8(2.0)$ & $1.7(1.6)$ & 1.05 & 0.41 \\
\hline Number of prescription medications & $7.3(4.3)$ & $6.6(3.7)$ & 1.05 & 0.05 \\
\hline
\end{tabular}

cer and PUD were significantly associated with ACE inhibitors therapy. Table 3 presents the univariate association between ace inhibitor therapy and other patient characteristics. Ace inhibitor use is significantly associated with being male, having higher glycosylated hemoglobin level (A1C), having higher body mass index (BMI, $\mathrm{kg} / \mathrm{m}^{2}$ ), having higher number of prescription medications, and being a non-drinker.

Univariate associations between potential confounding variables and cancer were evaluated (Table 4) and a logistic regression model constructed using cancer as the outcome and all potential confounders: gender, age (years), systolic blood pressure $(\mathrm{mmHg})$, glycosylated hemoglobin level (A1C) (mg\%), body mass index (BMI, kg/ $\mathrm{m}^{2}$ ), alcohol drinking (yes/no), cigarette smoking (yes/ no), number of comorbidities, and number of prescription medications. This model showed a significant association between cancer and the use of ACE inhibitors (OR = $0.59,95 \%$ CI $[0.39,0.89], P=0.01$ ) (Table 5). Other variables significantly associated with cancer history included age and number of prescription medications (Table 5).

Similarly, Table 6 presents the univariate associations between PUD and potential confounding variables. The logistic regression model showed a significant negative association with ACE inhibitors use (OR $=0.68,95 \% \mathrm{CI}$ $[0.46,1.00], P=0.05$ ) (Table 7$)$. Other variables significantly associated with PUD history included alcohol drinking and comorbid conditions.

\section{Discussion}

These data suggest a negative association of ACE inhibitor use with both cancer and PUD in a community based population of adults with diabetes.

Evidence from animal models suggests that angiotensin II stimulates neovascularization [17] and promote angiogenesis in neoplastic growth. Angiotensin II may also act as a mitotic factor by inducing or regulating gene expression in cell cycle progression [18]. The ACE inhibitor captopril has been shown to inhibit proliferation of a variety of cell types, including human breast cancer $[16,19,20]$, and to reduce tumor growth in experimental models of cancer $[21,22]$. Some epidemiological evidence also suggests protective effects of ACE inhibitors on cancer $[4,5]$. Here we present additional evidence of a potential negative association between cancer and the use of ACE inhibitors in a diabetic population.

Very few reports have looked at the association between ACE inhibitors and peptic ulcers. One study found that captopril significantly reduced the development of gastric ulcers in pylorus-ligated rats [23]. Another found that captopril and naloxone significantly reduced ulcer formation induced by stress in rats [24]. Mou et al. [25] determined that endogenous angiotensin II plays a role in the development of stress ulcers in rats with obstructive jaundice and that ACE inhibitors prevented their development. A report by Iakubov and Usmanova [26] indicated that prophylactic use of ACE inhibitors reduced indomethacininduced ulcers and erosions of the stomach in humans. They suggested that the reparative functions of the

Table 5: Multivariate associations between cancer and other patient characteristics

\begin{tabular}{lcc}
\hline Characteristic & Odds Ratio & $P$ \\
\hline ACE inhibitor therapy & 0.59 & 0.01 \\
Age, years & 1.02 & 0.02 \\
Male & 0.88 & 0.56 \\
Systolic Blood Pressure, $\mathrm{mmHg}$ & 1.01 & 0.28 \\
Glycosolated hemoglobin AIC, \% & 0.95 & 0.52 \\
Body mass index, kg/m ${ }^{2}$ & 0.98 & 0.15 \\
Alcohol drinking & 1.07 & 0.77 \\
Cigarette smoking & 0.68 & 0.22 \\
Number of comorbid conditions & 0.97 & 0.61 \\
Number of prescription medications & 1.09 & 0.01 \\
\hline
\end{tabular}

$N=974$ 
Table 6: Univariate associations between PUD and other patient characteristics.

\begin{tabular}{|c|c|c|c|c|}
\hline Characteristic & $\begin{array}{l}\text { PUD Patients } \\
\% \text { or mean ( } s d)\end{array}$ & $\begin{array}{l}\text { Non-PUD Patients } \\
\% \text { or mean ( } s d)\end{array}$ & Odds Ratio & $P$ \\
\hline Number of subjects & 143 & 860 & & \\
\hline ACE inhibitor therapy & $37.1 \%$ & $45.6 \%$ & 0.70 & 0.06 \\
\hline Age, years & $65.0(11.8)$ & $64.8(12.0)$ & 1.00 & 0.83 \\
\hline Male & $43.4 \%$ & $45.9 \%$ & 0.90 & 0.57 \\
\hline Systolic Blood Pressure, mmHg & I37.7 (19.5) & $140.7(19.6)$ & 1.00 & 0.09 \\
\hline Glycosolated hemoglobin AIC, \% & $7.1(1.3)$ & $7.1(1.3)$ & 1.00 & 0.71 \\
\hline Body mass index, $\mathrm{kg} / \mathrm{m}^{2}$ & $34.6(7.4)$ & $33.7(7.4)$ & 1.01 & 0.16 \\
\hline Alcohol drinking & $14.7 \%$ & $29.5 \%$ & 0.41 & $<0.001$ \\
\hline Cigarette smoking & $24.5 \%$ & $15.7 \%$ & 1.74 & 0.01 \\
\hline Number of comorbid conditions & $2.5(1.8)$ & $\mathrm{I} .5(\mathrm{I} .5)$ & 1.4 & $<0.001$ \\
\hline Number of prescription medications & $8.0(4.2)$ & $6.4(3.7)$ & 1.11 & $<0.001$ \\
\hline
\end{tabular}

mucous of the gastrointestinal track were influenced by a reduction of angiotensin II formation and activation of the renin-kallicrein-kinin system. These animal studies support the findings that ACE inhibitors may protect against PUD. We are aware of no prior studies of the association between ACE inhibitors and PUD in humans, but Sugimoto et al. [27] suggested that ACE gene polymorphisms were associated with cancer risk and gastric ulcers in Japan.

The mechanisms of the observed associations between ACE inhibition and the two diagnoses are unknown. It is possible that ACE inhibitors protect against the development of cancer or ulcer disease, although confirmation of these hypotheses must await additional investigation. Another interpretation of our results is the "treatment-risk paradox" in which the history of cancer or ulcer disease inhibits the use of ACE inhibitors, perhaps due to concerns of polypharmacy or intolerance of the medication due to the underlying disease. However, the prescribing information for ACE inhibitors does not discourage their use in either cancer or PUD and univariate analysis shows no significant differences between the number of comor-

Table 7: Multivariate associations between PUD and other patient characteristics

\begin{tabular}{lcc}
\hline Characteristic & Odds Ratio & $P$ \\
\hline ACE inhibitor therapy & 0.68 & 0.05 \\
Age, years & 1.00 & 0.96 \\
Male & 1.15 & 0.49 \\
Systolic Blood Pressure, $\mathrm{mmHg}$ & 0.99 & 0.23 \\
Glycosolated hemoglobin AIC, \% & 0.94 & 0.40 \\
Body mass index, kg/m ${ }^{2}$ & 1.01 & 0.57 \\
Alcohol drinking & 0.47 & 0.005 \\
Cigarette smoking & 1.51 & 0.09 \\
Number of comorbid conditions & 1.32 & $<0.001$ \\
Number of prescription medications & 1.01 & 0.68 \\
\hline
\end{tabular}

$N=974$ bidities in ACE inhibitor users and non-users. These facts argue against the "treatment-risk paradox" theory, although not conclusively.

This study has several strengths. First, the interviewed subjects were a randomly selected subset of a large population of patients receiving care in the Northeast, and are therefore likely to be representative of primary care patients generally. Second, all data on medications were obtained by direct observation in the patient's home and not from secondary sources. Third, multiple potential confounders were assessed and found to have no significant effect on the apparent associations between ACE inhibition and PUD and cancer.

This study has several limitations including lack of clinical confirmation of the comorbid diagnoses, and lack of information on the timing and duration of ACE inhibitor treatment relative to the onset of the comorbidities. As in any cross-sectional study, unmeasured confounders may be responsible for the apparent associations found.

\section{Conclusion}

These data suggest a potential protective association of ACE inhibitors for cancer and peptic ulcer disease in patients with diabetes. Further research is needed to confirm these associations and understand their mechanisms.

\section{Competing interests}

The authors declare that they have no competing interests.

\section{Authors' contributions}

MERN, CDM and BL contributed equally to all aspects of this work.

\section{Acknowledgements}

This research was supported by NIH grants ROI DK6I I67, K24 DK068380 (BL), and KOI CAI04I59 (MERN). 


\section{References}

I. Dzau VJ, Bernstein K, Celermajer D, Cohen J, Dahlof B, Deanfield J, Diez J, Drexler H, Ferrari R, van Gilst W, et al.: The relevance of tissue angiotensin-converting enzyme: manifestations in mechanistic and endpoint data. The American journal of cardiology 200I, 88(9A): IL-20L.

2. Jacobsen PK: Preventing end-stage renal disease in diabetic patients - dual blockade of the renin-angiotensin system (Part II). J Renin Angiotensin Aldosterone Syst 2005, 6(2):55-68.

3. Jacobsen PK: Preventing end stage renal disease in diabetic patients - genetic aspect (part I). J Renin Angiotensin Aldosterone Syst 2005, 6(I): I- I4.

4. Lever AF, Hole DJ, Gillis CR, McCallum IR, Mclnnes GT, MacKinnon PL, Meredith PA, Murray LS, Reid JL, Robertson JW: Do inhibitors of angiotensin-I-converting enzyme protect against risk of cancer? Lancet 1998, 352(9|23):|79-184.

5. Koh WP, Yuan JM, Sun CL, Berg D van den, Seow A, Lee HP, Yu MC: Angiotensin I-converting enzyme (ACE) gene polymorphism and breast cancer risk among Chinese women in Singapore. Cancer Res 2003, 63(3):573-578.

6. Huang ES, Meigs JB, Singer DE: The effect of interventions to prevent cardiovascular disease in patients with type 2 diabetes mellitus. Am J Med 200 I, I I I (8):633-642.

7. Lonn EM, Yusuf S, Jha P, Montague TJ, Teo KK, Benedict CR, Pitt B: Emerging role of angiotensin-converting enzyme inhibitors in cardiac and vascular protection. Circulation 1994, 90(4):2056-2069.

8. Sleight P: Angiotensin II and trials of cardiovascular outcomes. The American journal of cardiology 2002, 89(2A): I IA-I6A.

9. Yusuf S, Sleight P, Pogue J, Bosch J, Davies R, Dagenais G: Effects of an angiotensin-converting-enzyme inhibitor, ramipril, on cardiovascular events in high-risk patients. The Heart Outcomes Prevention Evaluation Study Investigators. N Engl J Med 2000, 342(3): | 45-I53.

10. Solski LV, Longyhore DS: Prevention of type 2 diabetes mellitus with angiotensin-converting-enzyme inhibitors. Am J Health Syst Pharm 2008, 65(1 0):935-940.

II. MacLean CD, Littenberg B, Gagnon M, Reardon M, Turner PD, Jordan C: The Vermont Diabetes Information System (VDIS): study design and subject recruitment for a cluster randomized trial of a decision support system in a regional sample of primary care practices. Clin Trials 2004, I(6):532-544.

12. Sangha O, Stucki G, Liang MH, Fossel AH, Katz JN: The Self-Administered Comorbidity Questionnaire: a new method to assess comorbidity for clinical and health services research. Arthritis Rheum 2003, 49(2): I56-I63.

13. Tamborlane WV, Kollman C, Steffes MW, Ruedy KJ, Dongyuan X, Beck RW, Chase P, Fox LA, Wilson DM, Tsalikian E: Comparison of fingerstick hemoglobin A Ic levels assayed by DCA 2000 with the DCCT/EDIC central laboratory assay: results of a Diabetes Research in Children Network (DirecNet) Study. Pediatr Diabetes 2005, 6( I): I3-16.

14. MacLean CD, Littenberg B, Kennedy AG: Limitations of diabetes pharmacotherapy: results from the Vermont Diabetes Information System study. BMC Fam Pract 2006, 7:50.

15. Ramos-Nino ME, MacLean CD, Littenberg B: Association between cancer prevalence and use of thiazolidinediones: results from the Vermont Diabetes Information System. BMC medicine 2007, 5: 17 .

16. Small W Jr, Molteni A, Kim YT, Taylor JM, Ts'ao CH, Ward WF: Mechanism of captopril toxicity to a human mammary ductal carcinoma cell line in the presence of copper. Breast Cancer Res Treat 1999, 55(3):223-229.

17. Fernandez LA, Twickler J, Mead A: Neovascularization produced by angiotensin II. J Lab Clin Med 1985, I 05(2): |4|-|45.

18. Sadoshima J, Aoki H, Izumo S: Angiotensin II and serum differentially regulate expression of cyclins, activity of cyclin-dependent kinases, and phosphorylation of retinoblastoma gene product in neonatal cardiac myocytes. Circ Res 1997, 80(2):228-24I.

19. Molteni A, Ward WF, Ts'ao CH, Taylor J, Small W Jr, Brizio-Molteni L, Veno PA: Cytostatic properties of some angiotensin I converting enzyme inhibitors and of angiotensin II type I receptor antagonists. Current pharmaceutical design 2003, 9(9):75 I-76।.

20. Small W Jr, Molteni A, Kim YT, Taylor JM, Chen Z, Ward WF: Captopril modulates hormone receptor concentration and inhibits proliferation of human mammary ductal carcinoma cells in culture. Breast cancer research and treatment 1997 , 44(3):217-224.

21. Hii SI, Nicol DL, Gotley DC, Thompson LC, Green MK, Jonsson JR: Captopril inhibits tumour growth in a xenograft model of human renal cell carcinoma. Br J Cancer 1998, 77(6):880-883.

22. Volpert OV, Ward WF, Lingen MW, Chesler L, Solt DB, Johnson MD, Molteni A, Polverini PJ, Bouck NP: Captopril inhibits angiogenesis and slows the growth of experimental tumors in rats. J Clin Invest 1996, 98(3):67I-679.

23. Rao SP, Sathiamoorthy A, Sathiamoorthy SS: Effect of angiotensin converting enzyme inhibitor (captopril) on gastric ulcer production in pylorus ligated rats. Indian J Physiol Pharmacol 1995 , 39(3):296-298.

24. Uluoglu C, Guney Z, Kilinc M, Bozkurt S, Ercan ZS: The effects of captopril and naloxone on restraint-cold-stress- and ethanolinduced gastric lesions in rats. General pharmacology 1998 , 30(5):701-704.

25. Mou D, Zhu X, Xu W, Du R: The pathogenetic role of endogenous angiotensin II in stress ulcer in obstructive jaundice rats. Chin Med J (Engl) 1998, I I I (4):309-3 I 2.

26. lakubov AV, Usmanova Sh E: [Prophylactic use of angiotensinconverting enzyme inhibitors in indomethacin-induced ulcer and erosion lesions of the stomach]. Likars'ka sprava/Ministerstvo okhorony zdorov'ia Ukrainy 2004:47-49.

27. Sugimoto $M$, Furuta $T$, Shirai $N$, Ikuma $M$, Sugimura $H$, Hishida $A$ : Influences of chymase and angiotensin I-converting enzyme gene polymorphisms on gastric cancer risks in Japan. Cancer Epidemiol Biomarkers Prev 2006, I 5( I 0):1929-1934.

\section{Pre-publication history}

The pre-publication history for this paper can be accessed here:

http://www.biomedcentral.com/1472-6823/8/17/prepub

Publish with BioMed Central and every scientist can read your work free of charge

"BioMed Central will be the most significant development for disseminating the results of biomedical research in our lifetime. "

Sir Paul Nurse, Cancer Research UK

Your research papers will be:

- available free of charge to the entire biomedical community

- peer reviewed and published immediately upon acceptance

- cited in PubMed and archived on PubMed Central

- yours - you keep the copyright
BioMedcentral 